\title{
Influence of laparoscopy and laparotomy on gasometry, leukocytes and cytokines in a rat abdominal sepsis model ${ }^{1}$
}

\author{
Influência da laparoscopia e laparotomia na gasometria, leucócitos \\ e citocinas em modelo de sepse abdominal em ratos
}

\author{
Irami Araújo Filho², Abraão Allen Honorato Sobrinho ${ }^{3}$, Amália Cinthia Meneses do Rego ${ }^{3}$, Ana Claudia M. de Amorim \\ Garcia $^{3}$, Daniele Pimentel Fernandes ${ }^{3}$, Thaís Medeiros Cruz ${ }^{3}$, Ticiana Cabral da Costa ${ }^{3}$, Aldo Cunha Medeiros ${ }^{4}$ \\ 1. Article from Nucleus of Experimental Surgery, Postgraduate Program in Health Sciences, Federal University of Rio Grande do Norte \\ (UFRN), Brazil. \\ 2. Postgraduate Fellow, Postgraduate Program in Health Sciences, UFRN, Brazil. \\ 3. Medical Student, Scientific Initiation Program, UFRN, Brazil. \\ 4. PhD, Chief, Nucleus of Experimental Surgery, UFRN, Brazil.
}

\begin{abstract}
Purpose: Laparoscopic surgery is associated with reduced surgical trauma, and less acute phase response, as compared with open surgery. Cytokines are important regulators of the biological response to surgical and anesthetic stress. The aim of this study was to determine if $\mathrm{CO}_{2}$ pneumoperitoneum would change cytokine expression, gas parameters and leukocyte count in septic rats. Methods: Wistar rats were randomly assigned to five groups: control (anesthesia only), laparotomy, $\mathrm{CO}_{2}$ pneumoperitoneum, cecum ligation and puncture by laparotomy, and laparoscopic cecum ligation and puncture. After 30 min of the procedures, arterial blood samples were obtained to determine leukocytes subpopulations by hemocytometer. TNFo, IL-1 $\beta$, IL-6 were determined in intraperitoneal fluid (by ELISA). Gas parameters were measured on arterial blood, intraperitoneal and subperitoneal exsudates. Results: Peritoneal TNF $\alpha$, IL-1 $\beta$ and IL-6 concentrations were lower in pneumoperitoneum rats than in all other groups $(\mathrm{p}<0.05)$. TNF $\alpha$, IL-1 $\beta$ and IL-6 expression was lower in the laparoscopic than in laparotomic sepsis $(\mathrm{p}<0.05)$. Rats from laparoscopic cecum ligation and puncture group developed significant hypercarbic acidosis in blood and subperitoneal fluid when compared to open procedure group. Total white blood cells and lymphocytes were significantly lower in laparoscopic cecum ligation and puncture rats than in the laparotomic $(p<0.01)$. Nevertheless, the laparotomic cecum ligation rats had a significant increase in blood neutrophils and eosinophils when compared with controls $(\mathrm{p}<0.05)$. Conclusions: This study demonstrates that the $\mathrm{CO}_{2}$ pneumoperitoneum reduced the inflammatory response in an animal model of peritonitis with respect to intraperitoneal cytokines, white blood cell count and clinical correlates of sepsis. The pneumoperitoneum produced hypercarbic acidosis in septic animals.
\end{abstract}

Key words: Pneumoperitoneum. Carbon Dioxide. Sepsis. Acidosis. Leucocytes.

\section{RESUMO}

Objetivo: A cirurgia laparoscópica está associada com trauma reduzido e baixa resposta na fase aguda do trauma, quando comparada com a cirurgia aberta. As citocinas e o balanço ácido-base são fatores importantes da resposta biológica ao trauma cirúrgico-anestésico. O objetivo deste estudo foi determinar se o pneumoperitôneo com $\mathrm{CO}_{2}$ altera a expressão das citocinas, a gasometria e a contagem diferencial de leucócitos em ratos com sepse abdominal. Métodos: Ratos Wistar foram

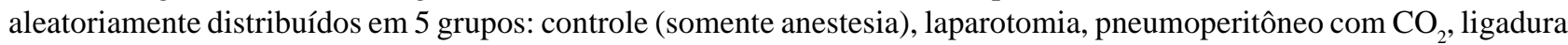
e punção do ceco por laparotomia, ligadura e punção do ceco por laparoscopia. Após 30 minutos dos procedimentos, sangue arterial foi colhido para leucometria diferencial em hemocitômetro. TNF $\alpha$, IL-1 $\beta$ e IL-6 foram dosadas no líquido intraperitoneal (por ELISA). Os parâmetros gasosos foram medidos no sangue arterial e nos exsudatos intraperitoneal e subperitoneal. Resultados: Os valores de TNF $\alpha$, IL-1 $\beta$ e IL-6 foram significantemente menores nos ratos submetidos ao pneumoperitôneo do que em todos os outros grupos ( $\mathrm{p}<0.05)$. Expressão de TNFo, IL-1 $\beta$ e IL-6 foi menor no grupo sepse induzida por laparoscopia do que por laparotomia $(\mathrm{p}<0.05)$. Os ratos submetidos a ligadura e punção do ceco via laparoscópica desenvolveram acidose hipercárbica no sangue arterial e exsudato subperitoneal, mais intensa do que no grupo sepse laparotômica. Leucopenia e linfopenia foram mais acentuadas no grupo sepse laparoscópica ( $<<0.01$ ). Entretanto, os animais submetidos a sepse laparotômica desenvolveram significante aumento de neutrófilos e eosinófilos quando comparados com os controles $(\mathrm{p}<0.05)$. Conclusões: Este estudo demonstrou que o pneumoperitôneo com $\mathrm{CO}_{2}$ contribuiu para reduzir a resposta inflamatória em ratos submetidos a modelo de sepse abdominal, no que diz respeito à expressão de citocinas intraperitoneais e leucometria diferencial. O pneumoperitôneo também contribuiu para instalação de acidose hipercárbica nos ratos sépticos.

Descritores: Pneumoperitônio. Dióxido de Carbono. Sepse. Acidose. Leucócitos. 


\section{Introduction}

Operative laparoscopy brought a new dimension to surgical practice, and many experimental and clinical studies have demonstrated feasibility, safety, cost-benefit, and pathophysiologic occurrences. The intraabdominal insufflation of carbon dioxide (CO2) is the most widely used technique for the creation of a pneumoperitoneum. Insufflation under a continuous monitoring of intraabdominal pressure throughout the surgical procedure provides adequate exposure of the operating field. As alternatives, different gases (e.g., helium, argon, nitrous oxide, air) may be used, but they have not been adopted clinically ${ }^{1,2,3,4,5,6}$. The actual knowledge concerning pneumoperitoneum are sometimes inconsistent about the physiologic consequences induced by insufflation of the peritoneal cavity with $\mathrm{CO}_{2}$. Results from animal models about the effects of a pneumoperitoneum in certain pathologic conditions are often alarming 7 . However, the clinical impact of these changes is unknown, since the majority of patients who undergo laparoscopic procedures do not exhibit any adverse clinical effects either in the short or the long-term course. Laparoscopíc surgery is applied increasingly to abdominal diseases complicated by diffuse or localized peritonitis such as appendicitis, perforated peptic ulcers and diverticulitis ${ }^{8,9}$. A specific paper has reported the use of laparoscopy in diverticulitis complicated by localized peritonitis with intra-abdominal abscess formation $^{10}$, and diagnostic laparoscopy is being advocated in diffuse peritonitis after blunt abdominal trauma ${ }^{11}$. However, a theoretical concern with the use of laparoscopic techniques in clinical cases complicated by intra-abdominal infection and peritonitis, is that carbon dioxide pneumoperitoneum may increase the risk of bacteraemia and sepsis by increasing intra-abdominal pressure. Some studies have demonstrated immunossuppressive effects of carbon dioxide on neutrophil and macrophage function. In one study, $\mathrm{CO}_{2}$ blocked superoxide release from activated polimorphonuclear leukocytes and significantly reduced the secretion of IL-1 from human peritoneal macrophages ${ }^{12}$. Whereas these effects might be considered beneficial from the standpoint of inflammation following elective surgery, experimental evidence suggests that the $\mathrm{CO}_{2}$ induced immunossuppression might be deleterious in the setting of infection $^{13}$. This may have an adverse effect on clinical outcome when compared with open procedures. Although some evidences, few data exist regarding the effect of pneumoperitoneum and increased intra-abdominal pressure on sepsis and physiological outcome. The aims of the current study were to investigate the influence of laparoscopic procedures, in particular CO2 insufflation, on the response to sepsis in an animal model-cecal ligation and puncture (CLP) in the rat. Clinical evolution, gasometry, pro-inflammatory cytokines and leukocytes were analyzed.

\section{Methods}

Male Wistar rats (Animal Colony from Nucleus of Experimental Surgery, Federal University of Rio Grande do Norte, Brazil), 12 to 13 weeks old, were housed in cages where standard chow and water were available ad libitum. The rats were acclimatized to the laboratory environment for 5 days on arrival and then fasted for 12 hours before any procedures. Anesthesia was obtained using pentobarbital $20 \mathrm{mg} / \mathrm{Kg}$ intraperitoneal and ketamine $50 \mathrm{mg} / \mathrm{Kg}$ intramuscular. All surgical procedures were performed under aseptic conditions. The animals were allowed to breathe spontaneously for the duration of the experiment. The group $C$ (control) rats were subjected to anesthesia only $(n=6)$. In the LAP (laparotomy) group $(n=7)$ the following procedures were performed: after anesthesia and antisepsis with povidone, a $5 \mathrm{~cm}$ laparotomy kept the peritoneal cavity exposed to the room air during 30 minutes and the abdominal wall was sutured with nylon $4-0$. The PNP rats $(n=7)$ were subjected to $\mathrm{CO}_{2}$ pneumoperitoneum using a Veress needle under $3 \mathrm{mmHg}$ for 30 minutes. On the CLP/LAP $(n=6)$ the CLP was performed after laparotomy. A cecum ligation and puncture (CLP) by laparoscopy under pneumoperitoneum were performed on the CLP/PNP rats ( $\mathrm{n}=6)$.

Cecal ligation and puncture - Pneumoperitoneum was achieved by introducing a Veress needle into the peritoneal cavity and insufflating (Endomed insufflator) the abdomen with $3 \mathrm{mmHg} \mathrm{CO}$. Laparoscopic procedures were performed using 3-mm instruments (Henke-Sass, Wolf ${ }^{\mathrm{TM}}$ ) introduced into the abdomen. Cecal ligation and puncture (CLP) consisted of dissection of the cecum, ligation midway between the ileocecal valve and the terminal cecum using a 3-0 chromic catgut tie, and 8-punctures of the isolated cecum with a hollow 25-gauge needle introduced through the abdominal wall. Laparotomy, for the open CLP group, consisted of a 5-cm midline abdominal incision. The duration of the total procedure, and therefore the duration of anesthesia, pneumoperitoneum, and laparotomy, was standardized to 30 minutes for all groups. Postoperatively, animals were resuscitated with a subcutaneous injection of lactated Ringer's (30 mL/kg) and were again housed in cages where water was available ad libitum. The experimental protocol was approved by the Research Ethics Committee of the Federal University of Rio Grande do Norte, Brazil, and adhered to the Guide for the Care and Use of Laboratory Animals, US National Research Council, 1996.

Gasometry and cytokines dosage - After the surgical procedures, $5 \mathrm{~mL}$ of buffered saline were injected in peritoneal cavity and the abdomen was softly massaged for 1 minute. Thirty minutes later, whole blood was collected by cardiac puncture and liquid exsudate was collected from peritoneal cavity and from subperitoneal space, using heparinized capilar tube, for determination of $\mathrm{pH}, \mathrm{pCO}_{2}$ and $\mathrm{pO}_{2}$ An automatic AVL (Roche ${ }^{\circledR}$ ) equipment was used. TNF $\alpha$, IL-1 $\beta$ and IL-6 were determined in the intraperitoneal exsudate, by enzyme-linked immunosorbent assay, using cytokine-kits from PeproTec (Rocky Hill, NJ,USA).

Leukometry - Animals were evaluated 24 hours postoperatively for clinical signs of CLP-induced sepsis (i.e., dark halo around the eyes, piloerection and lethargy). Whole blood was collected by cardiac puncture for leukocyte cell counts and the rats were then killed via anesthetic overdose. The determination of leukocyte cell counts was preformed using a commercially available automated cell counter (Abbott Cell-Dyn 3500R-CD 3500 $5 \mathrm{~L}$, USA). Data were expressed as mean \pm standard deviation. 
Statistical significance was established using the one way analysis of variance ANOVA followed by Newman-Keuls test. Probabilities less than 0.05 were considered significant.

\section{Results}

Cytokines release in peritoneal exsudate - Rats in the control, LAP and PNP groups exhibited normal activity and had no piloerection during the 24 hours after interventions. In contrast, all rats that underwent CLP exhibited decreased activity and significant piloerection. The cytokine levels on LAP rats were higher than PNP ones; however, the difference between these groups was not significant $(\mathrm{p}<0.05)$. Both surgical procedures, PNP/CLP and LAP/CLP, induced higher TNF $\alpha$, IL-1 $\beta$ and IL-6 in the peritoneal fluid than were found in the control group. In contrast, the peritoneal fluid TNF $\alpha$, IL-1 $\beta$ and IL-6 levels in the pneumoperitoneum (PNP) group were significantly lower than in the other groups $(\mathrm{p}<0.05)$. The PNP/CLP rats had a significantly lower elevation of TNF $\alpha$, IL-1 $\beta$ and IL-6 expression in the peritoneal fluid than LAP/CLP rats $(\mathrm{p}<0.05)$ (Figures 1, 2 and 3).

\section{IL-1 $\beta$ release}

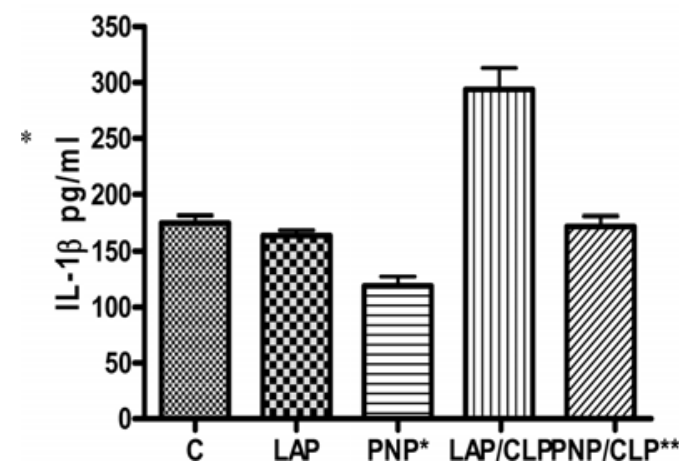

FIGURE 1 - No statistical difference was observed between groups $\mathrm{C}$ and LAP. When comparing IL-1 $\beta$ expression in groups LAP/CLP and PNP/ CLP**, the difference was significant. $(\mathrm{p}<0.05)$

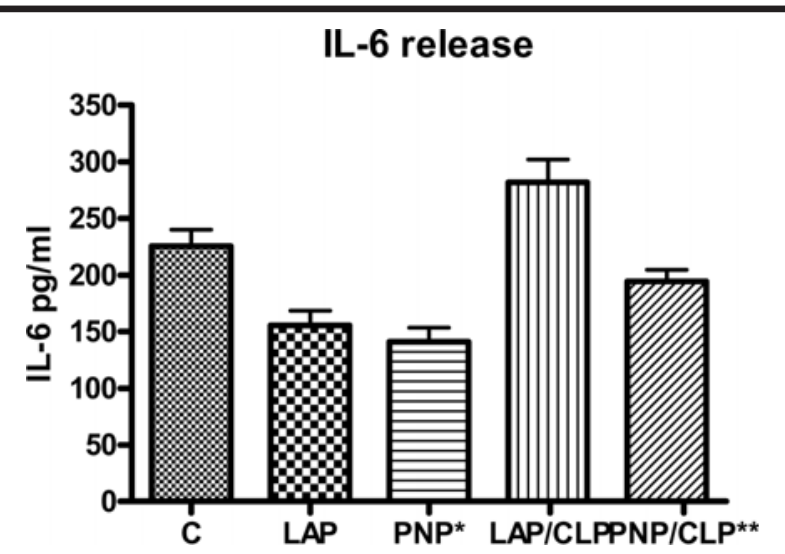

FIGURE 2 - The laparoscopic sepsis group (PNP/CLP) expressed IL-6 significantly lower than laparotomic group $(\mathrm{p}<0.05) .{ }^{*} \mathrm{p}<0,05$ vs $\mathrm{C}$, PNP/CLP, LAP/CLP

\section{$\mathrm{TNF} \alpha$ release}

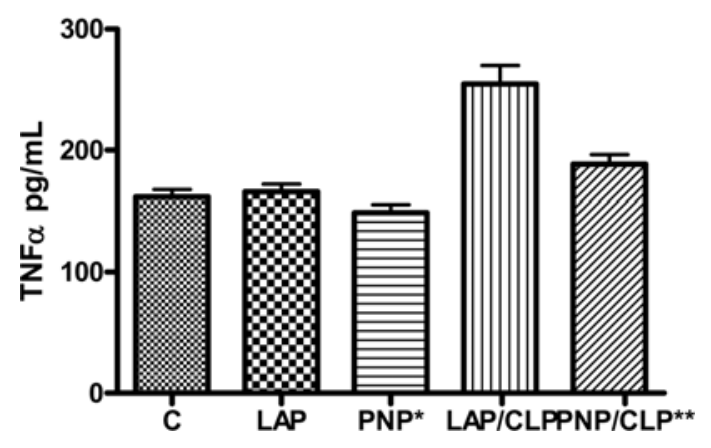

FIGURE 3 - TNF- $\alpha$ levels were significantly lower in laparoscopic sepsis rats (PNP/CLP) than when sepsis was induced by laparotomy $(\mathrm{LAP} / \mathrm{CLP})(\mathrm{p}<0.05)$

Gasometry - Arterial blood gas parameters (pH, pO2) in rats from the control group $(\mathrm{C})$ remained significantly higher than in rats from LAP, PNP and PNP/CLP groups $(\mathrm{p}<0.01)$. Rats from PNP/CLP group developed significant hypercarbic acidosis with mean $\mathrm{pH}$ of $7.18 \pm 0.05$ and $\mathrm{pCO}_{2} 60.7 \pm 10.2$ when compared to LAP/CLP group. The LAP/CLP rats acidosis was not hypercarbic (Table 1 ). The $\mathrm{pCO}_{2}$ was significantly higher on PNP/CLP rats than controls $(\mathrm{p}<0.01)$. Significantly reduced $\mathrm{pCO}_{2}$ was observed following LAP/CLP, compared to LAP, PNP and PNP/CLP $(\mathrm{p}<0.01)$. Intraperitoneal exsudate gas analysis revealed acidosis in the PNP group, and the difference was significant when compared with $\mathrm{C}$ and LAP groups $(p<0.01)$. However, the septic rats subjected to $\mathrm{CO}_{2}$ pneumoperitoneum (PNP/CLP) developed a profound intraperitoneal acidosis, as a consequence of $\mathrm{pCO}_{2}$ significantly higher $(\mathrm{p}<0.01)$ than in all other groups (Table 3$)$. In contrast, the $\mathrm{pO}_{2}$ was significantly lower than in $\mathrm{C}$ and LAP/CLP groups $(\mathrm{p}<0.05)$. While subperitoneal exsudate $\mathrm{pH}(6.5 \pm 0.05)$ following laparoscopic CLP using $\mathrm{CO}_{2}$ (PNP/CLP) was significantly lower $(\mathrm{p}<0.01)$ than in C, LAP and LAP/CLP rats, the difference did not reach statistical significance when compared with the acidotic $\mathrm{pH}(6.7 \pm 0.08)$ of PNP group (Table 3$)$. The $\mathrm{CO}_{2}$ pneumoperitoneum produced a significant increase in $\mathrm{pCO}_{2}$ in the subperitoneal exsudate, when compared with all the other groups $(\mathrm{p}<0.01)$.

TABLE 1 - Arterial blood gas parameters

\begin{tabular}{lllc}
\hline GROUP & \multicolumn{1}{c}{$\mathrm{pH}$} & \multicolumn{1}{c}{$\mathrm{pCO} 2$} & $\mathrm{pO} 2$ \\
\hline $\mathrm{C}$ & $7,36 \pm 0,08^{*}$ & $43,4 \pm 4.7 \S$ & $66,5 \pm 29$ \\
LAP & $7.23 \pm 0.03$ & $50.1 \pm 9.2$ & $62.4 \pm 19$ \\
PNP & $7.22 \pm 0.07$ & $48.6 \pm 9.6$ & $61.2 \pm 15$ \\
PNP/CLP & $7.18 \pm 0,05^{* *}$ & $60.7 \pm 10.2$ & $68,7 \pm 18$ \\
LAP/CLP & $7,26 \pm 0,04$ & $35.45 \pm 7.9 \dagger$ & $49.4 \pm 19$ \\
\hline
\end{tabular}

$* \mathrm{P}<0,01$ vs LAP, PNP, PNP/CLP; ${ }^{* *} \mathrm{p}<0.01$ vs LAP/CLP; $\S \mathrm{p}<0,05$ vs PNP/CLP; $\dagger \mathrm{p}<0.05$ vs LAP, PNP, PNP/CLP 
Leukocytes - White blood cell count in pneumoperitoneum and laparoscopic CLP was similar to those of controls (Table 4). Significantly reduced white cell counts were observed following laparoscopic CLP compared to open CLP $(\mathrm{p}<0.01)$. No significant difference in blood neutrophil and lymphocyte count was found among control, LAP, PNP and PNP/CLP rats. Nevertheless, the LAP/CLP rats had a significant increase in blood neutrophils when compared with controls ( $\mathrm{p}<0.05)$, as can be observed in Table 4 .

The PNP/CLP and LAP/CLP procedures produced a significant reduction in lymphocyte count, compared with controls $(\mathrm{p}<0.05)$. Additionally, the reduction in lymphocytes was significantly higher in open CLP (LAP/CLP) rats than in PNP/CLP $(\mathrm{p}<0.05)$. There was a significant reduction in eosinophil count in PNP, LAP/CLP and PNP/CLP, compared with controls $(\mathrm{p}<0.05)$. The decrease in LAP/CLP eosinophil was greater than in PNP/CLP rats.
TABLE 2 - Intraperitoneal exsudate gas parameters

\begin{tabular}{llll}
\hline GROUP & \multicolumn{1}{c}{$\mathrm{pH}$} & \multicolumn{1}{c}{$\mathrm{pCO} 2$} & $\mathrm{pO} 2$ \\
\hline $\mathrm{C}$ & $7,31 \pm 0,16$ & $33,6 \pm 7,6$ & $113,3 \pm 23$ \\
LAP & $7.30 \pm 0.1$ & $39.7 \pm 10$ & $95 \pm 31$ \\
PNP & $7.16 \pm 0.16^{* *}$ & $47 \pm 9.7$ & $102 \pm 15$ \\
PNP/CLP & $6,8 \pm 0,25^{*}$ & $86,5 \pm 41,3^{*}$ & $82,3 \pm 15 \S$ \\
LAP/CLP & $7,27 \pm 0,11$ & $48,3 \pm 9,4$ & $122,3 \pm 19$ \\
\hline
\end{tabular}

${ }^{*} \mathrm{P}<0,01$ vs $\mathrm{C}, \mathrm{LAP}, \mathrm{PNP}, \mathrm{LAP} / \mathrm{CLP} ; * * \mathrm{p}<0.01$ vs $\mathrm{C}, \mathrm{LAP} ; \S \mathrm{p}<0,05$ vs $\mathrm{C}, \mathrm{PNP} / \mathrm{CLP}$

TABLE 3 - Subperitoneal exsudate gas parameters

\begin{tabular}{llll}
\hline GROUP & $\mathrm{pH}$ & $\mathrm{pCO} 2$ & $\mathrm{pO} 2$ \\
\hline $\mathrm{C}$ & $7.16 \pm 0.2$ & $21 \pm 8$ & $146 \pm 12$ \\
$\mathrm{LAP}$ & $7.0 \pm 0.2$ & $18 \pm 9.6$ & $161 \pm 20$ \\
$\mathrm{PNP}$ & $6.7 \pm 0.08$ & $15 \pm 4.4$ & $130 \pm 19$ \\
PNP/CLP & $6.5 \pm 0.05^{*}$ & $46 \pm 3.8^{*}$ & $122 \pm 8.9^{*}$ \\
LAP/CLP & $7.16 \pm 0.1$ & $24 \pm 9.8^{* *}$ & $165 \pm 10.8^{* *}$ \\
\hline
\end{tabular}

${ }^{*} \mathrm{p}<0,01$ vs C, LAP, LAP/CLP; $* * \mathrm{p}<0,01$ vs PNP/CLP

TABLE 4 - Leukocyte blood counts after laparotomy, pneumoperitoneum and cecal ligation and puncture

\begin{tabular}{llllll}
\hline LEUCOCYTES & C & LAP & PNP & PNP/CLP & LAP/CLP \\
\hline WBC $(\mathrm{K} / \mu \mathrm{L})$ & $6.2 \pm 0.6 \int$ & $8.8 \pm 0.9 \phi$ & $4.8 \pm 0.6$ & $4.7 \pm 0.6 \dagger$ & $10.4 \pm 1.9$ \\
Neutrophil & $51.7 \pm 12$ & $49.1 \pm 12$ & $51.3 \pm 9.5$ & $60.8 \pm 11$ & $78.2 \pm 8^{*}$ \\
Lymphocyte & $32.5 \pm 10$ & $40 \pm 14$ & $36.4 \pm 9$ & $23 \pm 4.8^{* *}$ & $11.7 \pm 3$ \\
Eosinophils & $4 \pm 0.5$ & $3.9 \pm 0.3$ & $1.7 \pm 0.06 \S$ & $2 \pm 0.08$ & $0.8 \pm 0.01^{*}$ \\
\hline
\end{tabular}

C, control; LAP, laparotomy; PNP, pneumoperitoneum; PNP/CLP, pneumoperitoneum/cecum ligation and puncture; LAP/CLP, laparotomy/ cecum ligation and puncture; WBC, white blood count.

$\int \mathrm{p}<0.01$ vs LAP, LAP/CLP; $\phi \mathrm{p}<0.01$ vs PNP, PNP/CLP; $\dagger \mathrm{p}<0.01$ vs LAP/CLP; $* \mathrm{p}<0.01$ vs C, LAP, PNP, PNP/CLP; $* *$ $<0.01$ vs LAP,PNP; $\S p<0.05$ vs C,LAP, LAP/CLP.

\section{Discussion}

Because laparoscopic surgery is increasingly used for treating peritonitis and other septic states, a theoretic concern is related to the hypothesis that $\mathrm{CO}_{2}$ pneumoperitoneum may increase bacteremia with adverse effects for the patient. Some studies have reported technical feasibility of laparoscopic appendectomy, perforated peptic ulcer, perforated diverticulitis and other septic surgical situations ${ }^{14,15,16}$. They are small studies with low numbers of included patients, that can not give strong evidence about improved safety of laparoscopic surgery regarding septicemia. Study in rats showed that pneumoperitoneum causes intestinal ischemia with oxygen free radical production and bacterial translocation, related to mechanical pressure of $\mathrm{CO}_{2}{ }^{17}$. Other studies focused on whether a pneumoperitoneum amplifies the extent and severity of peritonitis or of bacteremia in various animal models ${ }^{18,19,20,21}$. Findings from these investigations are controversial. Whereas some authors reported no increase in bacteremia, intraperitoneal abscess formation, or correlates of sepsis, others reported increased bacterial translocation and severity of peritonitis and sepsis. Laparoscopic surgical technique requires the maintenance of a continuous positive intraperitoneal pressure in patients (approximately 10-15 $\mathrm{mmHg}$ ) for visualization and manipulation of the viscera. In cases of peritonitis, viable bacteria and bacterial byproducts (including endotoxin) exist free in the peritoneal cavity. Positive intraperitoneal pressure may increase bacteraemia and endotoxaemia, and thus may worsen clinical sepsis. As experience with laparoscopic surgery increases, its use in more debilitated and critically ill patients is being reported ${ }^{22}$. These patients often have sepsis and suffer from diffuse peritonitis of unclear aetiology, usually the result of a perforated viscus. It has not been clear whether a laparoscopic approach worsens the septic state or whether minimally invasive surgery is beneficial in these critically ill patients. Experimental model - Several animal models of peritoneal sepsis have been described varying in many respects, including the specific animal utilized and the method of sepsis ${ }^{20,23,24,25}$. The model of creating sepsis used in this study was adapted from the work of Hanly et $\mathrm{al}^{26}$. The convenience of the model of laparoscopic CLP in rats, used in the present experiment, is two-fold. First, the use of a septic animal model magnifies the stress induced by a surgical procedure to more clearly delineate the modifying effects of laparoscopy on the inflammatory response. Second, the combined stressors of bacterial contamination of the peritoneal cavity and bowel ischemia present following laparoscopic CLP provide an environment analogous to clinical situations in which laparoscopy is used to aid in the diagnosis and treatment of patients with 
peritonitis. The model used in this study presupposes that CLP caused sepsis and that the injury caused by CLP was equivalent between groups. We established the presence or absence of sepsis in rats by evaluating each rat for the presence or absence of periorbital dark halo, the presence or absence of piloerection and normal or decreased activity. All 12 rats that were subjected to CLP were identified as having clinical sepsis, and all 20 rats considered control, or that had received other procedures, were identified as not having sepsis.

Cytokines - In the present study we observed a significant decrease of TNFá, IL-1â and IL-6 in rats subjected to $\mathrm{CO}_{2}$ pneumoperitoneum with and without sepsis, and these findings coincided with acidosis in arterial blood, in intraperitoneal and subperitoneal exsudates. These data are in agreement with other investigators, who showed inhibition of human peritoneal macrophage cytokine production when these cells were incubated in an acidic extracellular environment, lowered the intracellular $\mathrm{pH}$ and attenuated cytokine release ${ }^{27}$. Similarly, Carozzi et al. ${ }^{28}$ showed decreased spontaneous release of IL-1, IL-6, IL-8, and TNF when incubations were performed in $\mathrm{pH} 5.5$ medium compared to much higher cytokine levels from cells incubated in medium with a $\mathrm{pH}$ of 7.4. In the present study the PNP and PNP/CLP rats exhibited arterial, intraperitoneal and subperitoneal acidosis, suggesting intracellular acidosis. West et al. ${ }^{32}$ have proposed relative intracellular acidosis as the mechanism by which the decrease in cytokines is exerted ${ }^{29}$. Redmond et al. ${ }^{30}$ showed that circulating monocytes obtained from patients after laparoscopic cholecystectomy exhibited reduced TNF release compared to those from patients who had open cholecystectomy. They also reported that peritoneal macrophages derived from animals undergoing $\mathrm{CO}_{2}$ laparoscopy released less TNF in response to lipopolyssacharides (LPS) than those undergoing air laparoscopy ${ }^{31}$. West et al. ${ }^{32}$ have shown that murine peritoneal macrophages exposed to $\mathrm{CO} 2$ in vitro exhibit inhibition of LPS-stimulated IL-1 and TNF cytokine release, suggesting that this effect is related to the influence of the $\mathrm{CO} 2$ environment. These findings contribute to explain the reduction of cytokine release when animals and patients are operated under effect of $\mathrm{CO}_{2}$ pneumoperitoneum. Whereas these effects might be considered beneficial from the standpoint of inflammation following elective surgery, one experimental study suggests that $\mathrm{CO}_{2}$ induced immunossuppression might be deleterious in the setting of infection ${ }^{13}$. The clinical significance of these findings remains unknown. In studies where laparoscopy was compared to open surgery for peritoneal infection such as appendicitis, there was no clear augmentation of infectious complications associated with the use of $\mathrm{CO}_{2}$ pneumoperitoneum ${ }^{33}$.

Gas analysis - The effect of pneumoperitoneum on hemodynamics and blood gas variables has been studied extensively in nonseptic animals ${ }^{34}$, and to a lesser degree in acute models of sepsis. In the present study, pneumoperitoneum alone and associated with CLP sepsis induced alterations of the acid-base balance, such as fall of $\mathrm{pH}$, and elevation of $\mathrm{pCO}_{2}$, in arterial blood, intraperitoneal and subperitoneal exsudate, without correlation to $\mathrm{pO}_{2}$. The decrease in $\mathrm{pH}$, that was more accentuated with CLP, was similar to what has been reported ${ }^{25}$. These findings were substantiated by other investigators, who found that intraabdominal $\mathrm{pH}$ diminishes with application of a $\mathrm{CO}_{2}$ pneumoperitoneum. $\mathrm{CO}_{2}$ used as an insufflation gas appeared to lower peritoneal, blood, and subcutaneous $\mathrm{pH}$ more than helium, which induced smaller changes ${ }^{35}$. Gandara et $\mathrm{al}^{36}$ stated that, in addition to $\mathrm{CO}_{2}$ absorption, this might be a phenomenon of tissue hypoperfusion. Nevertheless, in our study $\mathrm{pO}_{2}$ was not affected by pneumoperitoneum in septic and non septic rats. This finding can be explained by the fact that pneumoperitoneum was performed with $3 \mathrm{mmHg}$ pressure, sufficient to keep a normal and spontaneous respiration in rats. This pressure was used in rats by other investigators $^{37}$. By the way, Kuntz et $\mathrm{al}^{35}$. showed that, after insufflation with $\mathrm{CO}_{2}$, intraperitoneal $\mathrm{pH}$ was inversely related to the intraabdominal pressure.

Leukocytes - All rats subjected to CLP were found at autopsy having darkish, foul-smelling peritoneal fluid consistent with gross fecal contamination of the abdominal cavity. In the present study the total white cell count and circulating neutrophil were significantly lower following laparoscopic CLP using $\mathrm{CO}_{2}$ than following LAP/CLP. Laparotomic CLP produced a significant reduction in lymphocyte count compared to laparoscopic CLP using $\mathrm{CO} 2$, corroborating with data from other authors ${ }^{37}$. Another work has shown a profound drop in white blood cells in animals subjected to laparotomy or pneumoperitoneum under intraperitoneal inoculation of Escherichia coli, without difference between them. These data suggest that some results are conflicting, but there is a tendency to leucopenia and lymphopenia after laparoscopic CLP.

\section{Conclusions}

The $\mathrm{CO}_{2}$ pneumoperitoneum reduced the inflammatory response in an animal model of peritonitis with respect to intraperitoneal cytokines, white blood cell count and clinical correlates of sepsis. The pneumoperitoneum produced hypercarbic acidosis in septic rats.

\section{References}

1. Aneman A, Svensson M, Stenqvist O, Dalenback J, Lonnroth H. Intestinal perfusion during pneumoperitoneum with carbon dioxide, nitrogen, and nitric oxide during laparoscopic surgery. Eur J Surg. 2000;166:70-6.

2. Crabtree JH, Fishman A. Videoscopic surgery under local and regional anesthesia with helium abdominal insufflation. Surg Endosc. 1999;13:1035-9.

3. Eisenhauer DM, Saunders CJ, Ho HS, Wolfe BM. Hemodynamic effects of argon pneumoperitoneum. Surg Endosc. 1994; 8:315320 .

4. Fernandez-Cruz L, Saenz A, Taura P, Sabater L, Astudillo E, Fontanals J. Helium and carbon dioxide pneumoperitoneum in patients with pheochromocytoma undergoing laparoscopic adrenalectomy. World J Surg. 1998;22:1250-5.

5. Mann C, Boccara G, Grevy V, Navarro F, Fabre JM, Colson P. Argon pneumoperitoneum is more dangerous than $\mathrm{CO} 2$ pneumoperitoneum during venous gas embolism. Anesth Analg. 1997;85:1367-71.

6. Vezakis A, Davides D, Gibson JS, Moore MR, Shah H, Larvin M, McMahon MJ. Randomized comparison between low-pressure laparoscopic cholecystectomy and gasless laparoscopic cholecystectomy. Surg Endosc. 1999;13: 890-3.

7. Gurtner GC, Robertson CS, Chung SCS, Ling TKW, Ip SM, Li AKC. Effect of carcon dioxide pneumoperitoneum on bacteremia 
and endotoxemia in an animal model of peritonitis. Br J Surg. 1995;82:844-8.

8. Tate JJT, Dawson JW, Chung SCS, Lau WY, Li AKC. Laparoscopic versus open appendicectomy - prospective randomised trial. Lancet. 1993;342:633-7.

9. Lau JY, Lo SY, Ng EK, Lee DW, Lam YH, Chung SC. A randomized comparison of acute phase response and endotoxemia in patients with perforated peptic ulcers receiving laparoscopic or open patch repair. Am J Surg. 1998;175:325-7.

10.Phillips EH, Franklin M, Carroll BJ, Fallas MJ, Ramos R, Rosenthal D. Laparoscopic colectomy. Ann Surg. 1992; 216: 703-7.

11.Basso N, Chang TM, Howard TJ, Passaro E Jr. Laparoscopic surgery. A difference. Arch Surg. 1992;127:1269-71.

12.Kopernik G, Avinoach E, Grossman Y, Levy R, Yulzari R, Rogachev B, Douvdevani A. The effect of a high partial pressure of carbon dioxide environment on metabolism and immune functions of human peritoneal cells-relevance of carbon dioxide pneumoperitoneum. Am J Obstet Gynecol. 1998;179:1503-10.

13.Chekan EG, Nataraj C, Clary EM, Hayward TZ, Brody FJ, Stamat JC, Fina MC, Eubanks WS, Westcott CJ. Intraperitoneal immunity and pneumoperitoneum. Surg Endosc. 1999;13:1135-8.

14.Miserez M, Eypasch E, Spangenberger W, Lefering R, Troidl H. Laparoscopic and conventional closure of perforated peptic ulcer: a comparison. Surg Endosc. 1996;10:831-6.

15.Druart ML, Van Hee R, Etienne J, Cadiere GB, Gigot JF, Legrand M, Limbosch JM, Navez B, Tugilimana M, Van Vyve E, Vereecken L, Wibin E, Yvergneaux JP. Laparoscopic repair of perforated duodenal ulcer: a prospective multicenter clinical trial. Surg Endosc. 1997;11:1017-20.

16.Benoit J, Cruaud P, Lauroy J, Boutelier P, Champault G. Does laparoscopic treatment of abdominal infections generate bacteremias? Prospective study: 75 cases. J Chir. 1995;132:472-7.

17.Eleftheriadis E, Kotzampassi K, Papanotas K, Heliadis N, Sarris K.. Gut ischemia, oxidative stress, and bacterial translocation in elevated abdominal pressure in rats.

World J Surg. 1996;20:11-6.

18.Erenoglu C, Akin ML, Kayaoglu H, Celenk T, Batkin A. Is helium insufflation superior to carbon dioxide insufflation in bacteremia and bacterial translocation with peritonitis? J Laparoendosc Adv Surg Tech A. 2001;11:69-72.

19.Collet e Silva FD, Ramos RC, Zantut LF, Poggetti RS, Fontes B, Birolini D. Laparoscopic pneumoperitoneum in acute peritonitis does not increase bacteremia or aggravate metabolic or hemodynamic disturbances. Surg Laparosc Endosc Percutan Tech. 2000;10:305-10.

20.Ipek T, Paksoy M, Colak T, Polat E, Uygun N. Effect of carbon dioxide pneumoperitoneum on bacteremia and severity of peritonitis in an experimental model. Surg Endosc. 1998;12:432-5.

21.Ozguc H, Yilmazlar T, Zorluoglu A, Gedikoglu S, Kaya E . Effect of CO2 pneumoperitoneum on bacteremia in experimental peritonitis. Eur Surg Res. 1996;28:124-9.

22.Nordentoft T, Bringstrup FA, Bremmelgaard A, Stage JG. Effect of laparoscopy on bacteremia in acute appendicitis: a randomized controlled study. Surg Laparosc Endosc Percutan Tech. 2000;10:302-4.
23.Aguiar JLA, Moreira IEG, Chaves MM, Lopes SL, Santana V. Peritonite experimental: Modificação técnica do modelo de ligadura do ceco em ratos. An Fac Med Univ Fed Pernamb. 1996; 41: 59-62.

24.Kreimer F , Aguiar JLA, Castro C M M B, Lacerda CM, Reis T, Lisboa Jr F. Resposta terapêutica e inflamatória de ratos com peritonite secundária submetidos ao uso tópico de ampicilina/ sulbactam. Acta Cir Bras. 2005;20(suppl 1):31-9.

25.Clary DVM, Bruch SM, Lau CL, Ali A, Chekan EG, Garcia-Oria MJ, Eubanks S. Effects of pneumoperitoneum on hemodynamic and systemic immunologic responses to peritonitis in pigs. J Surg Res. 2002;108:32-8.

26.Hanly EJ, Bachman SL, Marohn MR, Boden JH, Herring AE, DeMaio A, Talamini MA. Carbon dioxide pneumoperitoneummediated attenuation of the inflammatory response is independent of systemic acidosis. Surgery. 2005;137:559-66.

27.Douvdevani A, Rapaport J, Konforty A. Intracellular acidification mediates the inhibitory effect of peritoneal dialysate on peritoneal macrophages. J Am Soc Nephrol. 1995; 6:207-.13.

28.Carozzi S, Caviglia PM, Nasini MG, Schelotto C, Santoni O, Pietrucci A. Peritoneal dialysis solution $\mathrm{pH}$ and $\mathrm{Ca} 2+$ concentration regulate peritoneal macrophage and mesothelial cell activation. ASAIO J. 1994; 40:20-3.

29.West MA, Hackam DJ, Baker J, Rodriguez JL, Bellingham J, Rotstein OD. Mechanism of decreased in vitro murine macrophage cytokine release after exposure to carbon dioxide. Ann Surg. 1997;226:179-90.

30.Redmond HP, Watson RWG, Houghton TO, Condron C, Watson RG, Bouchier-Hayes D. Immune function in patients undergoing open vs laparoscopic cholecystectomy. Arch Surg. 1994;129:1240-6.

31.Watson RWG, Redmond HP, McCarthy J, Burke PE, BouchierHayes D. Exposure of the peritoneal cavity to air regulates early inflammatory responses to surgery in a murine model. Br J Surg. 1995; 82:1060-5.

32.West MA, Baker J, Bellingham J. Kinetics of decreased LPSstimulated cytokine release by macrophages exposed to CO2. J Surg Res. 1996;63:269-74

33.Temple LK, Litwin DE, McLeod RS. A meta-analysis of laparoscopic versus open appencectomy in patients suspected of having acute appendicitis. Can J Surg. 1999;42:377-83.

34.Kheirabadi BS, Tuthill D, Pearson R, MacPhee M, Drohan W, Tuthill D. Metabolic and hemodynamic effects of $\mathrm{CO}_{2}$ pneumoperitoneum in a controlled hemorrhage model. J Trauma. 2001;50:1031-43.

35.Kuntz C, Wunsch A, Bodeker C, Bay F, Rosch R, Winderer J, Herfarth C. Effect of pressure and gas type on intraabdominal, subcutaneous, and blood pH in laparoscopy. Surg Endosc. 2000;14:367-71.

36.Gandara V, De Vega DS, Escrin N, Zorrilla IG. Acid-base balance alterations in laparoscopic cholecystectomy. Surg Endosc. 1997;11:707-10.

37.Hanly EJ, Mendoza-Sagaon M, Murata K, Hardacre J, De Maio A, Talamini MA. $\mathrm{CO}_{2}$ pneumoperitoneum modifies inflammation response to sepsis. Ann Surg. 2003;237:343-50.

\section{Correspondência:}

Aldo da Cunha Medeiros

Av. Miguel Alcides Araújo, 1889

59078-270 Natal-RN Brazil.

aldo@ufrnet.br
Conflict of interest: none Financial source: none

Received: October 10, 2005

Review: November 21, 2005

Accepted: December 19, 2005

\section{How to cite this article:}

Araújo Filho I, Honorato Sobrinho AA, Rego ACM, Garcia ACMA, Fernandes DP, Cruz TM, Costa TC, Medeiros AC. Influence of laparoscopy and laparotomy on gasometry, leukocytes and cytokines in a rat abdominal sepsis model. Acta Cir Bras. [serial on the Internet] 2006 Mar-Apr;21(2). Available from URL: http://www.scielo.br/acb 